\title{
The reactivity of linseed and soybean oil with different epoxidation degree towards vinyl acetate and impact of the resulting copolymer on the wood durability
}

\author{
M. Jebrane ${ }^{1 *}$, S. Cai ${ }^{1}$, C. Sandström ${ }^{2}$, N. Terziev ${ }^{1}$ \\ ${ }^{1}$ Department of Forest Products/Wood Science, Swedish University of Agricultural Sciences, P.O. Box 7008, SE-750 07 \\ Uppsala, Sweden \\ ${ }^{2}$ Department of Chemistry and Biotechnology, Swedish University of Agricultural Sciences, P.O. Box 7015, SE-750 07 \\ Uppsala, Sweden
}

Received 11 November 2016; accepted in revised form 9 January 2017

\begin{abstract}
Linseed (LO) and soybean oil (SO) were in-situ epoxidized with peracetic acid to produce different degree of epoxidized LO and epoxidized SO. For comparison purpose, commercial epoxidized linseed oil (ELO ${ }^{\circledR}$ ) and epoxidized soybean oil $\left(\mathrm{ESO}^{\circledR}\right)$ were also included in the study. The effect of epoxidation degree on the copolymerization reaction between epoxidized oils and vinyl acetate (VAc) was investigated. Results showed that a copolymer can be formed between VAc and epoxidized LO with high epoxy content, while no reaction occurred between VAc and SO or its epoxidized derivatives. As the most reactive monomer among the studied oils, the epoxidized LO with highest epoxy content (i.e. ELO $\left.{ }^{\circledR}\right)$ was mixed with VAc and then impregnated into the wood using three different $\mathrm{ELO}^{\circledR} / \mathrm{VAc}$ formulations either as solution or as emulsions. After curing, the impact of the resulting copolymer issued from the three tested formulations on the wood durability was evaluated. Results showed that the formulation comprising VAc, ELO ${ }^{\circledR}, \mathrm{H}_{2} \mathrm{O}, \mathrm{K}_{2} \mathrm{~S}_{2} \mathrm{O}_{8}$ and alkaline emulsifier (Formulation 3) can significantly improve wood's durability against white rot- (Trametes versicolor) and brown rot fungi (Postia placenta and Coniophora puteana). Treated wood of $8 \%$ weight percentage gain (WPG) was sufficient to ensure decay resistance against the test fungi with less than $5 \%$ mass loss.
\end{abstract}

Keywords: polymer synthesis, epoxidation, plant oil, vinyl acetate, decay resistance

\section{Introduction}

There has been growing interests in biomaterials prepared from natural resources in recent years. Plant oils are extracted from naturally-occurring raw materials which are biodegradable, renewable and non-toxic. Depending on the degree of unsaturation in triglyceride, oils can be classified into three classes, i.e. drying, semi-drying and non-drying oils [1]. For example, linseed oil (LO) derived from the seeds of flax plant (Linum usitatissimum) is a typical drying oil, while the soybean oil (SO) extracted from the seeds of the soybean (Glycine max) is regarded as semi-drying oil [2]. Although the plant oils have environmental and economic benefits, their direct utilization as alternative chemicals is limited due to their low reactivity.

The reactivity of the unmodified plant oil is mainly attributable to the esters and double bonds in triglyceride. The transesterification by alcoholysis or acidolysis can proceed at esters of the triglyceride [3], while the double bonds can undergo radical or cationic copolymerization with vinyl monomers or through auto-oxidation with other triglycerides $[1,3]$. A wide range of thermosets were prepared by cationic copolymerization of oils with alkene comonomers, such as divinylbenzene and styrene, resulting in copolymers

*Corresponding author, e-mail: mohamed.jebrane@s,slu.se (C) BME-PT 
ranging from elastomers to tough and rigid plastics [4-7]. With respect to the radical polymerization, since the double bonds in most of the oils are nonconjugated which are inactive for radical polymerization, their reactivity can be chemically improved by conjugating the double bonds or converting double bonds into more active groups, such as epoxy [8, 9]. The epoxidized plant oils can be chemically produced from plant oil by in-situ epoxidation with hydrogen peroxide and acetic acid in the presence of sulfuric acid as catalyst [10-12]. The conversion of double bonds into epoxide groups increases the reactivity of oils due to the ring strain in the epoxy group. The further functionalization of the epoxidized oils can be achieved by the ring-opening reaction of epoxy groups. Variety of electrophiles, such as $\mathrm{HCl}, \mathrm{HBr}$ and carboxylic acid, can be used for the hydroxylation of epoxidized oil while amine, alcohol and thiol can serve as nucleophiles for the ring-opening reaction of epoxy groups [13]. The obtained polyols can react with isocyanates to produce polyurethane (PU) which has been extensively used in the coatings, adhesives, sealants and elastomers areas [13]. In addition to their utilization as starting materials for many industrial chemical products, plant oils have frequently been applied as eco-friendly products for wood protection as a result of the hydrophobic character of plant oils [14-16]. However, due to lack of covalent bonding between the water repellents and wood's hydroxyl groups, plant oils cannot fully prevent the process of water absorption in a long term [17]. Moreover, the checking in wood exposed outdoors can also be overcome by oil $[17,18]$. Plant oils, in general, have no fungicidal properties but can inhibit wood decay fungi to some extent. Studies showed that the minimum oil retention for wood protection was $320 \mathrm{~kg} \cdot \mathrm{m}^{-3}$ [16], while low oil retention $\left(156-208 \mathrm{~kg} \cdot \mathrm{m}^{-3}\right)$ proved to have no significant effect against the fungal growth [19]. The inhibition of fungal growth is presumably caused by the reduced moisture content in wood and the scarcity of oxygen supply due to the pore space plugging by oil [16]. However, with high oil retention, wood becomes heavy and expensive. Recent studies revealed that the durability of treated wood with low oil loading can be improved by either adding fungicide (such as boric acid) or bio-oil which itself contains antifungal phenolic compounds (such as crude tall oil)
$[16,17,20]$. Plant oil treated wood is suggested to be used in hazard class 2 or 3 (above ground covered or uncovered) due to temporary inhibition of water absorption [17, 21].

To increase the durability of plant oil treated wood, a possible route is to copolymerize plant oil with other vinyl monomers forming copolymers. The plant oil and vinyl monomers were impregnated and cured in wood to form an insoluble polymer bulked in the cell wall and the resulting copolymer was expected to show improved decay resistance. A previous study reported the radical copolymerization of commercial epoxidized linseed oil $\left(\mathrm{ELO}^{\circledR}\right)$ with vinyl acetate (VAc) [22]. As a typical vinyl monomer, VAc is a colorless liquid which is mainly used as precursor for the production of polyvinyl acetate (PVAc) or the polyvinyl alcohol (PVA). As a low toxic and relatively cheap thermoplastic, PVAc found its application in the fields of wood and paper processing, civil engineering, packaging and binding industry adhesives and coatings, construction and civil engineering, textile and leather, biomedicine, etc. [23, 24]. Waterborne dispersions containing PVAc have been extensively used as adhesives for wood or wood-based materials [25, 26]. The incorporation of hydrophobic ELO ${ }^{\circledR}$ into PVAc polymer chains results in products with improved waterproofing properties. It was reported that the epoxidation of some double bonds in plant oils makes the residual double bonds more reactive towards radical polymerization with VAc [22]. In parallel, control experiment between VAc and LO which contains more double bonds was carried out in the same condition but no reaction was occurred under the same condition [22]. In radical polymerization, since the relative reactivity of the monomers is associated with the resonance stability, steric effect and polarity influenced by the substituents [27, 28], the introduction of the epoxy groups upon epoxidation changes the polarity of the residual double bonds in oil molecules, thus making oils easier to react with other alkene co-monomers through radical polymerization. The objective of the present work was to study the effects of epoxidation degree of $\mathrm{LO}$ and $\mathrm{SO}$ on the copolymerization reaction between the oil derivatives and VAc. The most reactive oil monomer among the studied oil was chosen to further copolymerize with VAc in wood to evaluate the treatment impact on the wood decay resistance. 


\section{Experimental}

\subsection{Chemicals}

ELO $^{\circledR}$, Commercial epoxidized soybean oil $\left(\mathrm{ESO}^{\circledR}\right)$ and $\mathrm{SO}$ were obtained from Traditem $\mathrm{GmbH}$ (Hilden, Germany), while LO was supplied by Oppboga Säteri (Fellingsbro, Sweden). Brij ${ }^{\circledR}$ S 100 (polyoxyethylene stearyl ether, average $\left.M_{\mathrm{n}}=4.670 \mathrm{~g} \cdot \mathrm{mol}^{-1}\right)$ $(\mathrm{HLB}=18)$, cetyltrimethylammonium bromide $(\mathrm{CTAB})$, sorbitane monooleate $\left(\operatorname{Span}^{\circledR} 80\right)(\mathrm{HLB}=$ 4.3), sodium carbonate, sulfuric acid (95-98 wt\%) and VAc ( $\geq 99 \mathrm{wt} \%$, 3-20 ppm hydroquinone) were purchased from Sigma-Aldrich (Schnelldorf, Germany). In addition, the hydrogen peroxide (33 wt $\%$ ) was obtained from VWR Chemicals (France). Benzoyl peroxide (BPO), glacial acetic acid (AA, $100 \mathrm{wt} \%$ ) and potassium persulfate $\left(\mathrm{K}_{2} \mathrm{~S}_{2} \mathrm{O}_{8}\right)$ were supplied by Merck (Darmstadt, Germany). All the chemicals were reagent grade and used as received.

\subsection{Instrumentation}

ATR-FTIR spectra of oil and polymer samples were acquired in the range of $4000-450 \mathrm{~cm}^{-1}$ (spectral resolution $4 \mathrm{~cm}^{-1}, 16$ scans) on a Perkin Elmer Spectrum One FT-IR Spectrometer equipped with a Universal Attenuated Total Reflectance Accessory (UATR). The sample to be analysed was brought into contact with diamond crystal of the ATR accessory. The spectra of oily samples were recorded by dropping oily samples directly on the diamond crystal of the ATR accessory, while the polymer samples were made into films and the polymer spectra were collected with constant pressure applied on polymer films ensuring a close contact between polymer samples and the ATR diamond crystal. The spectra obtained by ATRFTIR were baseline-corrected and normalized afterwards.

The ${ }^{1} \mathrm{H}$-NMR spectra for both oils and polymers were acquired in $\mathrm{CDCl}_{3}$ solution on a $600 \mathrm{MHz}$ Bruker Avance III spectrometer. Chemical shifts in the spectra were reported in $\delta$ [ppm], using residual solvent signal as the internal standard $\left(\mathrm{CHCl}_{3}, \delta=7.26 \mathrm{ppm}\right)$.

\subsection{Synthesis of partly epoxidized oils}

The SO or LO was firstly mixed with glacial AA at room temperature, followed by adding $\mathrm{H}_{2} \mathrm{SO}_{4}$ (72 wt\%) dropwise under stirring at $30^{\circ} \mathrm{C}$. As oxidizing agent, $\mathrm{H}_{2} \mathrm{O}_{2}(30 \mathrm{wt} \%)$ was then added slowly to the solution by a funnel to avoid substantial increase of temperature due to the exothermic reaction between $\mathrm{H}_{2} \mathrm{O}_{2}$ and AA. Since epoxidation at high temperature increases the chance of ring-opening of the epoxy group [11, 29], the present epoxidation reaction was carried out at moderate temperatures (30$50^{\circ} \mathrm{C}$ ), and epoxidized oils with different epoxy content can be obtained by simply regulating the reaction time when temperature reached $50^{\circ} \mathrm{C}$. The solution was heated at $30^{\circ} \mathrm{C}$ for $30 \mathrm{~min}$ (count from the time when $\mathrm{H}_{2} \mathrm{O}_{2}$ was added to the solution) and then kept at $40{ }^{\circ} \mathrm{C}$ for $30 \mathrm{~min}$ and finally heated at $50^{\circ} \mathrm{C}$ for $1,3,6$ and $7 \mathrm{~h}$ to prepare the epoxidized LO with various epoxy content, i.e. ELO4, ELO3, ELO2 and ELO1 respectively. Likewise, the SO was also heated at $30^{\circ} \mathrm{C}$ for $30 \mathrm{~min}$ and then at $40^{\circ} \mathrm{C}$ for $30 \mathrm{~min}$ and finally heated at $50^{\circ} \mathrm{C}$ for $1,2,3$ and $5 \mathrm{~h}$ to prepare the partly epoxidized SO, namely ESO4, ESO3, ESO2 and ESO1 respectively. The molar ratio of double bonds in oil: AA: $\mathrm{H}_{2} \mathrm{O}_{2}$ was kept at 1:1.5:0.5, with $2 \mathrm{wt} \% \mathrm{H}_{2} \mathrm{SO}_{4}$ used as catalyst.

Since the area under each signal in ${ }^{1} \mathrm{H}-\mathrm{NMR}$ spectra is proportional to the amount of corresponding functional group, the ${ }^{1} \mathrm{H}-\mathrm{NMR}$ is used to monitor the conversion of double bonds to epoxy groups and quantify the epoxy content in different degree of epoxidized oils. The signal of triglyceride at 4.12-4.31 ppm ( $-\mathrm{C}_{2}-\mathrm{CH}-\underline{\mathrm{C}}_{2}-$ of the glycerol moiety) was chosen as an internal standard for quantification, which does not interfere with other signals and remains unchanged after epoxidation. The signal area at 2.85$3.21 \mathrm{ppm}$ (epoxy group, $-\mathrm{C} \underline{\mathrm{H}}-\mathrm{O}-\mathrm{C} \underline{\mathrm{H}}-$ ) relative to the internal standard is used to calculate the number of formed epoxy groups in each oil molecule, from which the degree of epoxidation (DOE) can be calculated according to the Equation (1) [9, 29],

$\mathrm{DOE}=\frac{\text { number of epoxide groups }}{\text { number of starting double bonds }} \cdot 100 \%$

We assumed that the $\mathrm{ESO}^{\circledR}$ and $\mathrm{ELO}^{\circledR}$ purchased from supplier have higher DOE values $(<100 \%$ DOE) than that of their respective synthesized partly epoxidized SO and epoxidized LO. However, since there was no available information regarding the number of their starting double bonds, and their epoxidation method and origins are unknown, it was not possible to determine the exact DOE values for $\mathrm{ESO}^{\circledR}$ and $\mathrm{ELO}^{\circledR}$ in the present study.

\subsection{Synthesis of copolymers}

VAc-plant oil copolymer was synthesized in aqueous medium, without solvent and protective colloid, by mixing a catalytic amount of $\mathrm{K}_{2} \mathrm{~S}_{2} \mathrm{O}_{8}$ with deionized 
water, oil, and VAc in round-bottom flask equipped with stirrer and a reflux condenser. The stoichiometric ratio of $\mathrm{VAc} / \mathrm{oil} / \mathrm{H}_{2} \mathrm{O}$ was kept at 1:1:1 by weight with $0.25 \mathrm{wt} \% \mathrm{~K}_{2} \mathrm{~S}_{2} \mathrm{O}_{8}$ as initiator. The mixture was heated at $80^{\circ} \mathrm{C}$ for $120 \mathrm{~min}$ and the obtained polymers were washed several times with deionized water to remove unreacted monomers and oligomers, and then with diethyl ether to completely remove unreacted residual oil monomer.

\subsection{Formulation preparation and wood impregnation}

In order to facilitate the wood impregnation, a stable and homogenous solution containing VAc and oil without continuous agitation is required. Three options were tested in the study: Formulation 1 which includes VAc and $\mathrm{ELO}^{\circledR}$ using VAc-soluble BPO as initiator, while small amounts of emulsifier(s) are required to guarantee a stable VAc-oil in water (Formulation 2 and 3). The feed ratio of VAc to ELO ${ }^{\circledR}$ was kept at 1:1 by weight in all the described formulations. Formulation 1 was produced by dissolving the initiator BPO $(2 \mathrm{wt} \%)$ in VAc, and then adding oil to the VAc solution. Formulation 2 was prepared by dissolving water-soluble $\mathrm{K}_{2} \mathrm{~S}_{2} \mathrm{O}_{8}(0.25 \mathrm{wt} \%)$ in deionized water, followed by adding sodium carbonate $(1 \mathrm{wt} \%)$ and oil under constant agitation. Non-ionic emulsifier Brij ${ }^{\circledR} \mathrm{S} 100$ (3 wt\%) and VAc were added to the solution. The feed ratio of VAc, oil, and $\mathrm{H}_{2} \mathrm{O}$ was $1: 1: 1$ by weight. The Brij ${ }^{\circledR} \mathrm{S} 100$ used in Formulation 2 was substituted by combined emulsifiers of CTAB (2.6 wt \%) and $\mathrm{Span}^{\circledR} 80(1.6 \mathrm{wt} \%)$ in Formulation 3, and the process of preparing Formulation 3 is similar to the Formulation 2 without the addition of $\mathrm{Na}_{2} \mathrm{CO}_{3}$.

The impregnation of wood samples with the abovementioned formulations was performed in a stainless-steel reactor. Rueping empty cell and full cell processes were employed to cover a wide range of solution uptake. Wood samples after impregnation were moved to sealed glass containers in which a small amount of VAc was poured at the bottom beforehand. A saturated VAc atmosphere was created for the purpose of compensating the loss of impregnated VAc inside wood during the curing. After curing for $168 \mathrm{~h}$ at $90^{\circ} \mathrm{C}$, all samples were dried at $103^{\circ} \mathrm{C}$ for $24 \mathrm{~h}$. The final weight percentage gain (WPG) after drying is defined by Equation (2):

$\mathrm{WPG}[\%]=\left[\frac{M_{\mathrm{t}}-M_{\mathrm{u}}}{M_{\mathrm{u}}}\right] \cdot 100 \%$

where $M_{\mathrm{u}}$ is the oven-dry weight of specimens before treatment, and $M_{\mathrm{t}}$ is the oven-dry weight of specimens after treatment.

\subsection{Durability}

The durability tests were carried out according to standard EN 113 [30] to evaluate the decay resistance of treated wood produced from different formulations. After water leaching according to EN 84 [31] and re-conditioning, treated samples were exposed to the white rot fungus Trametes versicolor and brown rot fungi Postia placenta and Coniophora puteana in a climate room $\left(25^{\circ} \mathrm{C}\right.$ and $65 \%$ relative humidity). After 16 weeks' incubation, the samples were cleaned gently and then dried at $103^{\circ} \mathrm{C}$ for $24 \mathrm{~h}$; the fungal resistance of treated samples was evaluated by measuring the mass loss (ML). The durability of the treated samples can be classified in accordance to standard EN 350-1 [21], in which the ML of the treated wood is compared with the ML of the untreated wood. The durability class (DC) of treated samples can be classified as follows: 1-very durable, 2-durable, 3-moderately durable, 4-slightly durable, and 5-nondurable.

\section{Results and discussion}

\subsection{Characterization and quantification of epoxidized oil with various epoxy content}

Epoxidation can convert double bonds in triglyceride molecules into epoxide groups, however, residual double bonds can still remain due to the incomplete epoxidation. The chemical structure of a typical partly epoxidized oil is illustrated in Figure 1.

Stacked plot of ${ }^{1} \mathrm{H}-\mathrm{NMR}$ spectra of LO, ELO ${ }^{\circledR}$ and four synthesized partly epoxidized LO (i.e. ELO1,

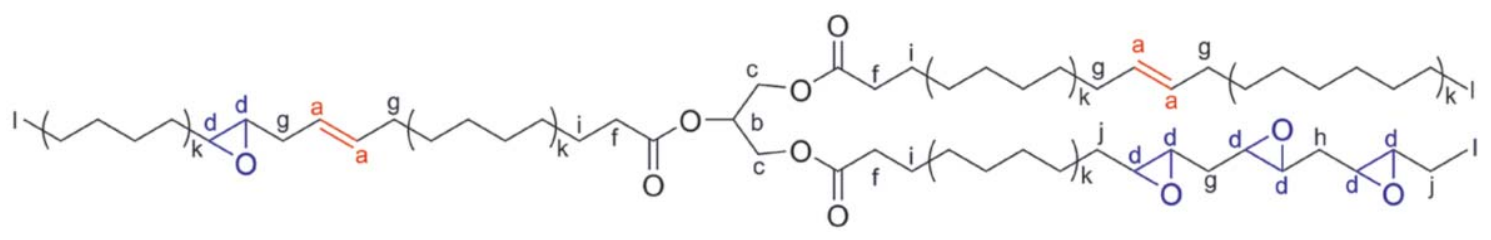

Figure 1. Chemical structure of partly epoxidized oil. Letter for each proton correlates with those shown in Figure 2. 


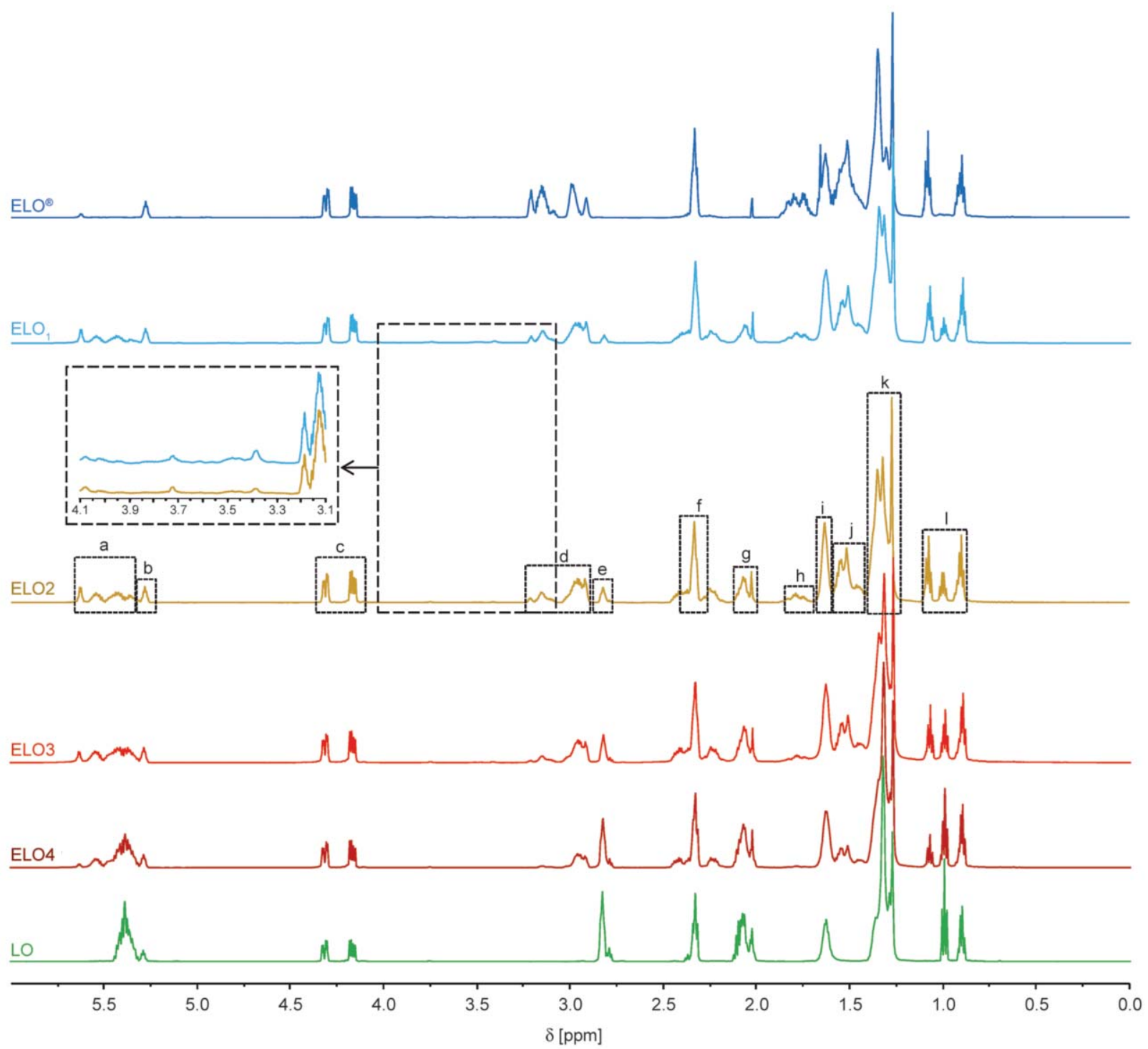

Figure 2. ${ }^{1} \mathrm{H}-\mathrm{NMR}$ spectra of LO, ELO ${ }^{\circledR}$ and four partly epoxidized LO. The letters assigned to signals coincide with those shown in Figure 1. Signal at 3.3-4.1 ppm for ELO1 and ELO2 are enlarged.

ELO2, ELO3, ELO4) are shown in Figure 2. Since similar ${ }^{1} \mathrm{H}-\mathrm{NMR}$ spectra can be observed for $\mathrm{SO}$ and its derivatives apart from the intensity difference in the double bonds and epoxy region, only the spectra of LO and its derivatives are shown here.

Assignments for signals based on the partly epoxidized LO in the range of $\delta=0-6 \mathrm{ppm}$ are displayed in Table 1 [9, 32-34]. As characteristic signals of ELO $^{\circledR}$, the epoxy groups are observed at 2.85$3.21 \mathrm{ppm}$ region. An enlargement of this region allows distinguishing between mono-epoxides at 2.85$3.03 \mathrm{ppm}$, and adjacent epoxides at 3.04-3.21 ppm. Additionally, the signals for $\alpha-\mathrm{CH}_{2}-$ of epoxy groups are shown at $1.39-1.56$ and at $1.68-1.85 \mathrm{ppm}$. Regarding LO, the characteristic signals of double bonds in LO are observed at 5.29-5.47 ppm, and the signals for $\alpha-\mathrm{CH}_{2}-$ of the double bonds are observed at
$1.97-2.11$ and at 2.75-2.82 ppm. With respect to the partly epoxidized oil, signals attributable to the double bonds adjacent to epoxy groups are shown at $5.48-5.68 \mathrm{ppm}$.

As the area under each ${ }^{1} \mathrm{H}-\mathrm{NMR}$ signal is proportional to the quantities of equivalent protons presented in the molecule, the DOE of partly epoxidized oils can be calculated by measuring the area under each signal of epoxy groups in the respective spectra. The 'number of epoxy groups' defined in Equation (1) for partly epoxidized LO or partly epoxidized SO can be determined by measuring the area under signal $\mathrm{d}$ in the spectra. Since the partly epoxidized LO or partly epoxidized $\mathrm{SO}$ is originated from $\mathrm{LO}$ or $\mathrm{SO}$, the area under signal a in the spectra of $\mathrm{LO}$ or $\mathrm{SO}$ can be regarded as the 'number of starting double bonds' for partly epoxidized LO or partly epoxidized SO in 
Table 1. Assignment of signals of ${ }^{1} \mathrm{H}-\mathrm{NMR}$ spectra for partly epoxidized LO. Letters described here are in line with those shown in Figure 2.

\begin{tabular}{|c|c|l|}
\hline Signal & \multicolumn{1}{|c|}{$\begin{array}{c}\text { Chemical shift, } \boldsymbol{\delta} \\
\text { [ppm] }\end{array}$} & \multicolumn{1}{|c|}{ Structure with assignment } \\
\hline$a$ & $5.29-5.68$ & $-\mathrm{C} \underline{\mathrm{H}}=\mathrm{C} \underline{\mathrm{H}}-$ \\
\hline$b$ & $5.23-5.28$ & $-\mathrm{CH}_{2}-\mathrm{C} \underline{\mathrm{H}}-\mathrm{CH}_{2}-$ of the glycerol backbone \\
\hline$c$ & $4.12-4.31$ & $-\mathrm{C}_{2}-\mathrm{CH}-\mathrm{C}_{2}-$ of the glycerol backbone \\
\hline$d$ & $2.85-3.21$ & $>\mathrm{C} \underline{\mathrm{H}}-$ at epoxy group \\
\hline$e$ & $2.75-2.82$ & $-\mathrm{CH}=\mathrm{CH}-\underline{\mathrm{H}}_{2}-\mathrm{CH}=\mathrm{CH}-$ \\
\hline$f$ & $2.27-2.35$ & $\alpha-\underline{\mathrm{H}}_{2}$ to the carbonyl group $-\mathrm{OCO}-\mathrm{CH}_{2}-$ \\
\hline$g$ & $1.97-2.11$ & $-\underline{\mathrm{H}}_{2}-\mathrm{CH}=\mathrm{CH}-$ in acyl chain \\
\hline$h$ & $1.68-1.85$ & $\alpha-\underline{\mathrm{H}}_{2}-$ adjacent to two epoxy groups \\
\hline$j$ & $1.56-1.67$ & $\beta-\underline{\mathrm{C}}_{2}$ to the carbonyl group $-\mathrm{OCO}^{-} \mathrm{CH}_{2}-\underline{\mathrm{C}}_{2}-$ \\
\hline$j$ & $1.39-1.56$ & $\alpha-\underline{\mathrm{C}}_{2}-$ to epoxy group \\
\hline$l$ & $1.20-1.39$ & saturated methylene group $-\left(\underline{\mathrm{CH}}_{2}\right)_{\mathrm{n}}-\mathrm{in}$ acyl chain \\
\hline & $0.84-1.09$ & terminal $-\mathrm{C} \underline{H}_{3}$ \\
\hline
\end{tabular}

Equation (1). The values of signal area at $a$ and $d$ can be determined by assuming the signal area of internal standard at $c$ to be 4 . As shown in Table 2, increasing the epoxidation reaction time results in an increase of DOE for partly epoxidized oil. However, the $\mathrm{ELO}^{\circledR}$ and $\mathrm{ESO}^{\circledR}$ were purchased and used as received; their epoxidation method and origins are unknown. Accordingly, the DOE of ELO ${ }^{\circledR}$ and $\mathrm{ESO}^{\circledR}$ cannot be determined in this study. By comparison, Farias et al. [29] studied the epoxidation of SO at

Table 2. Measured area under signal $d(\delta=2.85-3.21 \mathrm{ppm})$ for determination of the DOE [\%], and yield of copolymer by reacting VAc with different degree of epoxidized LO or epoxidized SO (VAc/oil = 1/1, $(\mathrm{w} / \mathrm{w}))$.

\begin{tabular}{|c|c|c|c|}
\hline & $\begin{array}{c}\text { Area under } \\
\text { signal } d\end{array}$ & $\begin{array}{l}\text { DOE } \\
{[\%]}\end{array}$ & $\begin{array}{c}\text { Yield after reaction with VAc } \\
{[\%]}\end{array}$ \\
\hline \multicolumn{4}{|c|}{ Linseed oil } \\
\hline $\mathrm{ELO}^{\circledR}$ & 11.00 & - & 54.3 \\
\hline ELO1 & 6.99 & 56.5 & 49.2 \\
\hline ELO2 & 6.90 & 55.8 & 37.6 \\
\hline ELO3 & 5.65 & 45.7 & 1.3 \\
\hline ELO4 & 3.31 & 26.8 & oligomers \\
\hline $\mathrm{LO}^{*}$ & 0.00 & - & oligomers \\
\hline \multicolumn{4}{|c|}{ Soybean oil } \\
\hline $\mathrm{ESO}^{\circledR}$ & 7.96 & - & 53.8 \\
\hline ESO1 & 5.53 & 69.0 & 47.5 \\
\hline ESO2 & 3.95 & 49.3 & 46.3 \\
\hline ESO3 & 3.15 & 39.3 & 47.6 \\
\hline ESO4 & 2.32 & 28.9 & 49.4 \\
\hline $\mathrm{SO}^{*}$ & 0.00 & - & 50.6 \\
\hline
\end{tabular}

*The areas under signal $a(\delta=5.29-5.68 \mathrm{ppm})$ in the LO and SO's spectra were 12.36 and 8.01 respectively. $110^{\circ} \mathrm{C}$ using bis(acetyl-acetonato)dioxo-molybdenum (VI) as catalyst in the presence of tert-butyl hydroperoxide as oxidizing agent. The $2-24 \mathrm{~h}$ reaction resulted in DOE in the range of $41-54 \%$, which is comparable to the epoxidation method described in the present study.

Although the reaction time for producing ELO1 is $1 \mathrm{~h}$ longer than that of ELO2, the difference between DOE of ELO1 (56.5\%) and ELO2 (55.8\%) is small. Since the formed epoxides can be opened by the $\mathrm{H}_{2} \mathrm{SO}_{4}$ and AA in the solution, the epoxidation carried out at higher temperature or/and longer times can contributes to ring opening of the formed epoxy groups. It was reported that protons in $\alpha$ position of secondary hydroxyl caused by ring opening of epoxide $(\mathrm{C} \underline{\mathrm{H}}-\mathrm{OH})$ and protons in $\alpha$ position of ether link due to oligomerization $(\mathrm{C} \underline{\mathrm{H}}-\mathrm{O}-\mathrm{CH})$ show signals at 3.3-4.1 ppm [13]. The intensity difference between ELO1 and ELO2 in the region of 3.3-4.1 ppm is highlighted in Figure 2. Compared to the ELO2, the ELO1 shows higher signal intensity at 3.3-4.1 ppm which is presumably caused by the acid-catalyzed ring opening of the epoxy groups. Consequently, the DOE of ELO1 is close to that of ELO2 in spite of difference in epoxidation time.

The FTIR spectra of LO, partly epoxidized LO and ELO $^{\circledR}$ are displayed in Figure 3. The peaks attributable to the double bonds are observed at both 3011 and $1654 \mathrm{~cm}^{-1}$ in LO, while the ELO ${ }^{\circledR}$ is characterized by an absorption peak of epoxy groups found at $821 \mathrm{~cm}^{-1}$. The characteristic peaks of both epoxy 


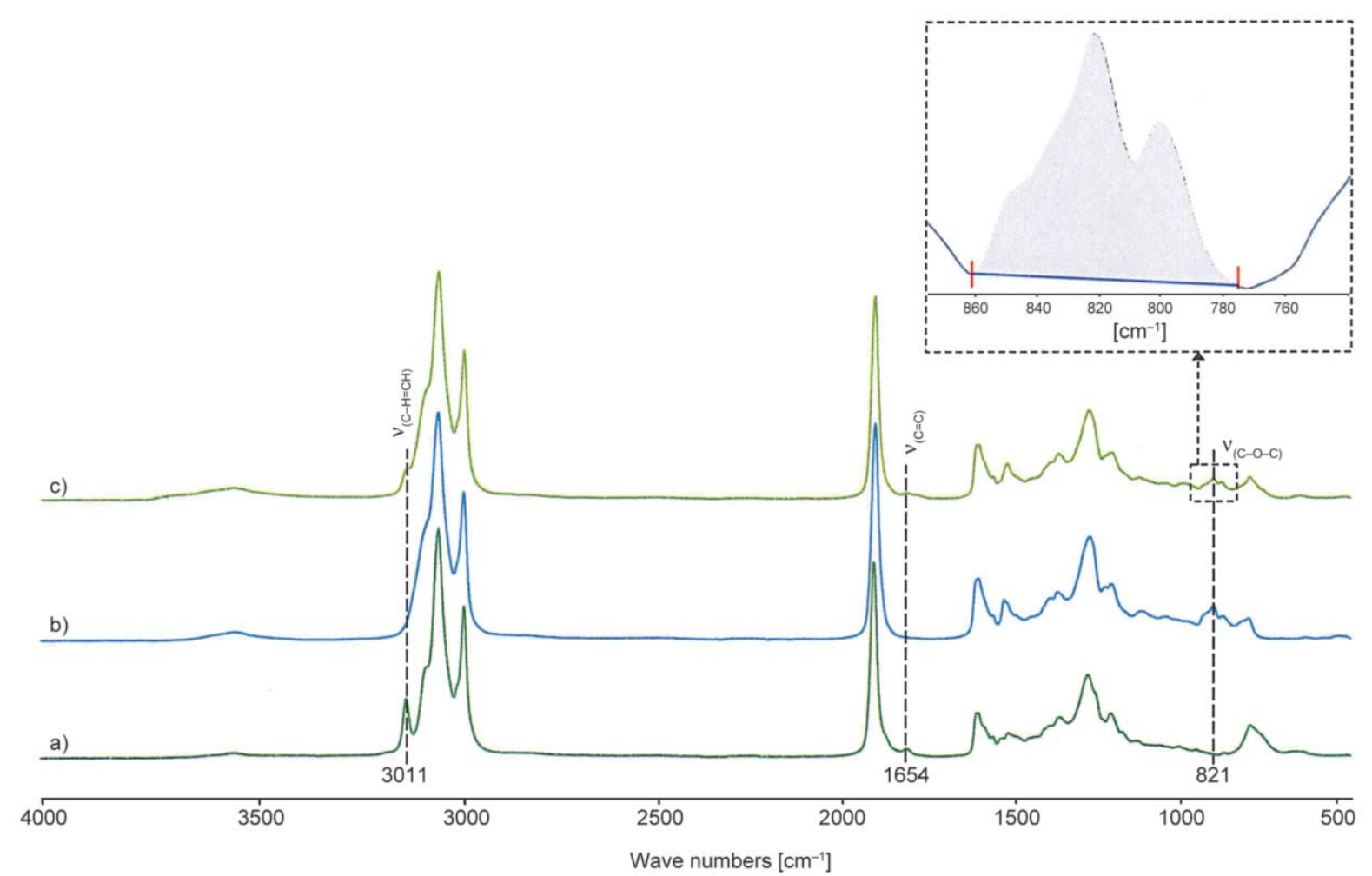

Figure 3. FTIR spectra of LO (a), ELO ${ }^{\circledR}$ (b) and partly epoxidized LO (c) together with enlarged scale of peak (epoxy group) at $821 \mathrm{~cm}^{-1}$

groups and double bonds appear in the spectrum of partly epoxidized LO, but their intensities are comparatively weaker. The peak corresponding to the stretching vibration of oxirane ring at $821 \mathrm{~cm}^{-1}$ is highlighted and magnified in Figure 3 to calculate the change of peak area upon epoxidation.

Study on the FTIR spectra of SO, partly epoxidized $\mathrm{SO}$ and $\mathrm{ESO}^{\circledR}$ are comparable to the spectra of LO and its derivatives shown above, therefore, the comparison among $\mathrm{SO}$, partly epoxidized $\mathrm{SO}$ and $\mathrm{ESO}^{\circledR}$ are not shown here. According to Beer-Lambert law, the absorbance is proportional to the concentration of the analyte. Thus, the peak area at $821 \mathrm{~cm}^{-1}$ in the ATR-FTIR is proportional to the number of epoxy groups in the oil, which can be used to estimate the epoxy content in oil. Since the ${ }^{1} \mathrm{H}-\mathrm{NMR}$ can also be used for the quantitative measurement of the epoxy groups in oil molecules, the relationship between FTIR and ${ }^{1} \mathrm{H}-\mathrm{NMR}$ in measuring the epoxy content in oil molecules can be obtained. The area of FTIR spectral peak is measured at $821 \mathrm{~cm}^{-1}$ (Table 3) while ${ }^{1} \mathrm{H}-\mathrm{NMR}$ considers the area under signal at $\delta=2.85$ $3.21 \mathrm{ppm}$. The peak area ratio (partly epoxidized LO/ $\mathrm{ELO}^{\circledR}$ and partly epoxidized $\mathrm{SO} / \mathrm{ESO}^{\circledR}$ ) obtained from FTIR spectra is plotted as function of signal area ratio calculated from ${ }^{1} \mathrm{H}-\mathrm{NMR}$. As shown in Figure 4, linear regression coefficients of 0.96 and
Table 3. Area under the FTIR spectral peak at $821 \mathrm{~cm}^{-1}$ for different degree of epoxidized $\mathrm{LO}$ and $\mathrm{ESO}^{\circledR}$

\begin{tabular}{|l|c|c|c|c|c|c|}
\hline Oil type & ELO $^{\circledR}$ & ELO1 & ELO2 & ELO3 & ELO4 & LO \\
\hline Area & 1.99 & 1.09 & 1.08 & 0.74 & 0.34 & 0 \\
\hline Oil type & ESO $^{\circledR}$ & ESO1 & ESO2 & ESO3 & ESO4 & SO \\
\hline Area & 0.86 & 0.57 & 0.36 & 0.28 & 0.22 & 0 \\
\hline
\end{tabular}

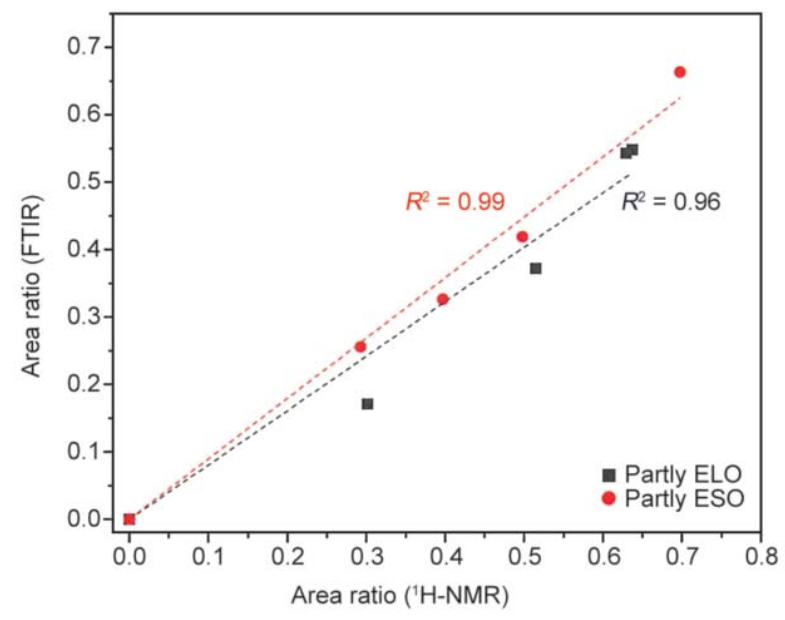

Figure 4. Fitted linear relationship between the peak (signal) area ratio (partly epoxidized LO/ELO ${ }^{\circledR}$ and partly epoxidized $\mathrm{SO} / \mathrm{ESO}^{\circledR}$ ) measured by FTIR and ${ }^{1} \mathrm{H}-\mathrm{NMR}$ regarding the epoxy content in oil molecules

0.99 are obtained for partly epoxidized LO and partly epoxidized SO respectively, which indicates strong 
correlation between the two characterization methods for determination of the epoxy content.

\subsection{Synthesis and spectroscopic characterization of copolymers}

To investigate the effects of epoxidation degree of LO and SO on the copolymerization reaction between epoxidized oil and VAc, the yield after was determined (Table 2). The feed ratio of VAc to oil was kept at $1 / 1(\mathrm{w} / \mathrm{w})$ and the reaction was performed at $80^{\circ} \mathrm{C}$ for $2 \mathrm{~h}$ with $0.25 \mathrm{wt} \%$ initiator. Reaction between VAc and epoxidized LO with high epoxy content yielded more product than that of the epoxidized LO having relatively low epoxy content. Epoxidized LO with lower epoxy content (such as ELO3, ELO4) and LO without epoxy groups were not reactive enough to react with VAc, thus only liquid oligomer were obtained after $2 \mathrm{~h}$ reaction. An illustration of ${ }^{1} \mathrm{H}-\mathrm{NMR}$ spectrum of VAc-epoxidized LO (high epoxy content) copolymer is shown in Figure 5. The spectrum shows the coexistence of signals from both epoxidized LO and PVAc, which suggests the presence of molecules from both starting compounds. The signals attributed to the PVAc backbone are shown at 1.77, 2.02 and $4.87 \mathrm{ppm}$ in spectrum, while signals attributable to the epoxidized LO fragments can be observed at $5.61(-\mathrm{C} \underline{H}=\mathrm{C} \underline{\mathrm{H}}-), 5.25,4.12-$ 4.31, 2.85-3.21 (epoxide), 2.31, and 0.84-1.09 ppm. Nevertheless, because of the low reactivity and higher molecular weight of the triglycerides, the intensity of the signals attributable to epoxidized LO moieties appear to be weak compared to that of the PVAc signals shown in the same spectrum. The oil inclusion in the synthesized copolymers were calculated to be 0.87 , 0.85 and $0.74 \mathrm{~mol} \%$ by taking the ratio of area under signal at 4.12-4.31 ppm $\left(-\mathrm{CH}_{2}-\mathrm{C}-\mathrm{CH}_{2}-\right.$ of the glycerol backbone in triglyceride) and 4.78-5.07 ppm (PVAc methine) for the formulations of VAc-ELO ${ }^{\circledR}$, VAc-ELO1 and VAc-ELO2 respectively.

Regarding $\mathrm{SO}$ and its derivatives, the signals corresponding to the oil moieties can hardly be identified in products obtained by reaction between VAc and SO or its derivatives according to the spectroscopic analysis. Their resulting spectra are analogous to that of the homopolymer PVAc. Figure 6 compares the spectrum of VAc-ESO ${ }^{\circledR}$ with those of VAc-ELO3, VAcELO2, VAc-ELO1 and VAc-ELO ${ }^{\circledR}$ in the range of 2.9-5.5 ppm. Signals of oil moieties can be found in the spectra of VAc-ELO2, VAc-ELO1 and VAcELO $^{\circledR}$ in which the epoxidized LO with high epoxy

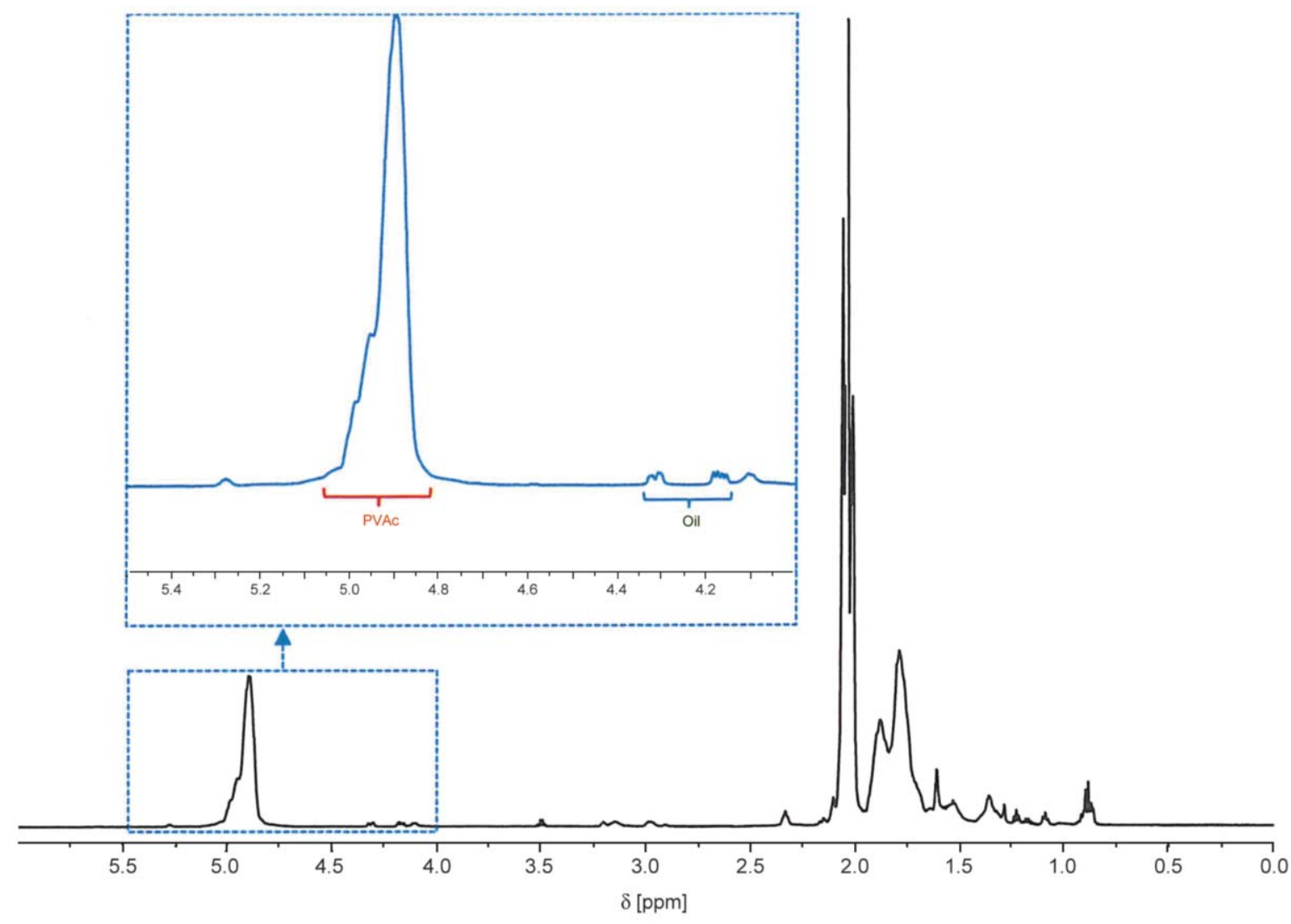

Figure 5. ${ }^{1} \mathrm{H}-\mathrm{NMR}$ spectrum of VAc-epoxidized LO copolymer $($ VAc/oil = 1/1, $(\mathrm{w} / \mathrm{w}))$ 
content was used, while signals shown in VAc$\mathrm{ESO}^{\circledR}$ and VAc-ELO3 spectra are identical to PVAc. It is assumed that the reaction between VAc and epoxidized oil depends not only on the degree of epoxidation, but also on the types of oil used (i.e. degree of unsaturation). Oil with higher iodine value (IV) can be epoxidized to oil having more epoxy groups, which shows increased reactivity towards VAc, while oils with low IV were less reactive. Consequently, maximum epoxidized LO (i.e. ELO $^{\circledR}$ ) is considered to be the most reactive monomer compared to the other partly epoxidized LO and SO in copolymerization reaction with VAc. It was reported that the presence of epoxy groups can activate the residual double bonds in oil, which could be explained by the change of inductive effect due to the epoxidation of some double bonds [22]. The polymerization reaction between VAc and $\mathrm{ELO}^{\circledR}$ follows two steps mechanism. The first step involves the radical initiation of VAc polymerization by persulfate initiator, followed by the second step in which the propagation of VAc monomers takes place. The formed radical intermediate of PVAc grafted onto the triglycerides by radical activation of the residual double bonds in triglycerides. The linkage between PVAc and ELO ${ }^{\circledR}$ is evidenced by the emergence of new signals observed at 31.0 and $15.3 \mathrm{ppm}$ shown in the ${ }^{13} \mathrm{C}-\mathrm{NMR}$ spectrum of VAc-ELO ${ }^{\circledR}$ copolymer [22].

In addition to the ${ }^{1} \mathrm{H}-\mathrm{NMR}$, the ATR-FTIR was used to prove the reaction between VAc and $\mathrm{ELO}^{\circledR}$ or ELO2 by identification of characteristic vibrations from both reagents. Figure 7 shows the FTIR spectra of $E L{ }^{\circledR}$, PVAc and copolymers. The spectrum of synthesized copolymer shows three distinct absorption peaks in the range $2850-3000 \mathrm{~cm}^{-1}$, which corresponds to $\mathrm{C}-\mathrm{H}$ stretching vibration mainly from epoxidized LO. Although the intensity of oil signals in copolymer decrease with respect to the unreacted oil, the intensity of the absorption peaks attributable to the epoxidized LO moieties at $2850-3000 \mathrm{~cm}^{-1}$ region is higher in VAc-ELO ${ }^{\circledR}$ copolymer than in VAcELO2 copolymer. The difference in the peak intensity implies that the inclusion of oil in VAc-ELO ${ }^{\circledR}$ copolymer is more than that in the VAc-ELO2, which indicates a higher reactivity of $\mathrm{ELO}^{\circledR}$ than partly epoxidized LO in polymerization reaction with VAc. Moreover, a shift in the characteristic absorption peak of the epoxy groups $\left(821 \mathrm{~cm}^{-1}\right)$ to lower wavenumbers $\left(798 \mathrm{~cm}^{-1}\right)$ with decreased intensity is also observed in the copolymer spectrum.

\subsection{Decay resistance of VAc-ELO ${ }^{\circledR}$ treated wood}

Previous ${ }^{1} \mathrm{H}-\mathrm{NMR}$ investigation revealed that almost no signals corresponding to the oil moieties can be observed in the spectra after reaction between VAc and SO derivatives or epoxidized LO with low epoxy content. Therefore, epoxidized LO with high epoxy content $\left(\right.$ i.e. $\left.\mathrm{ELO}^{\circledR}\right)$ was selected for further investigation to study the impact of the VAc-ELO ${ }^{\circledR}$ treatment on the wood durability. A stable and homogenous solution containing VAc and $\mathrm{ELO}^{\circledR}$ without

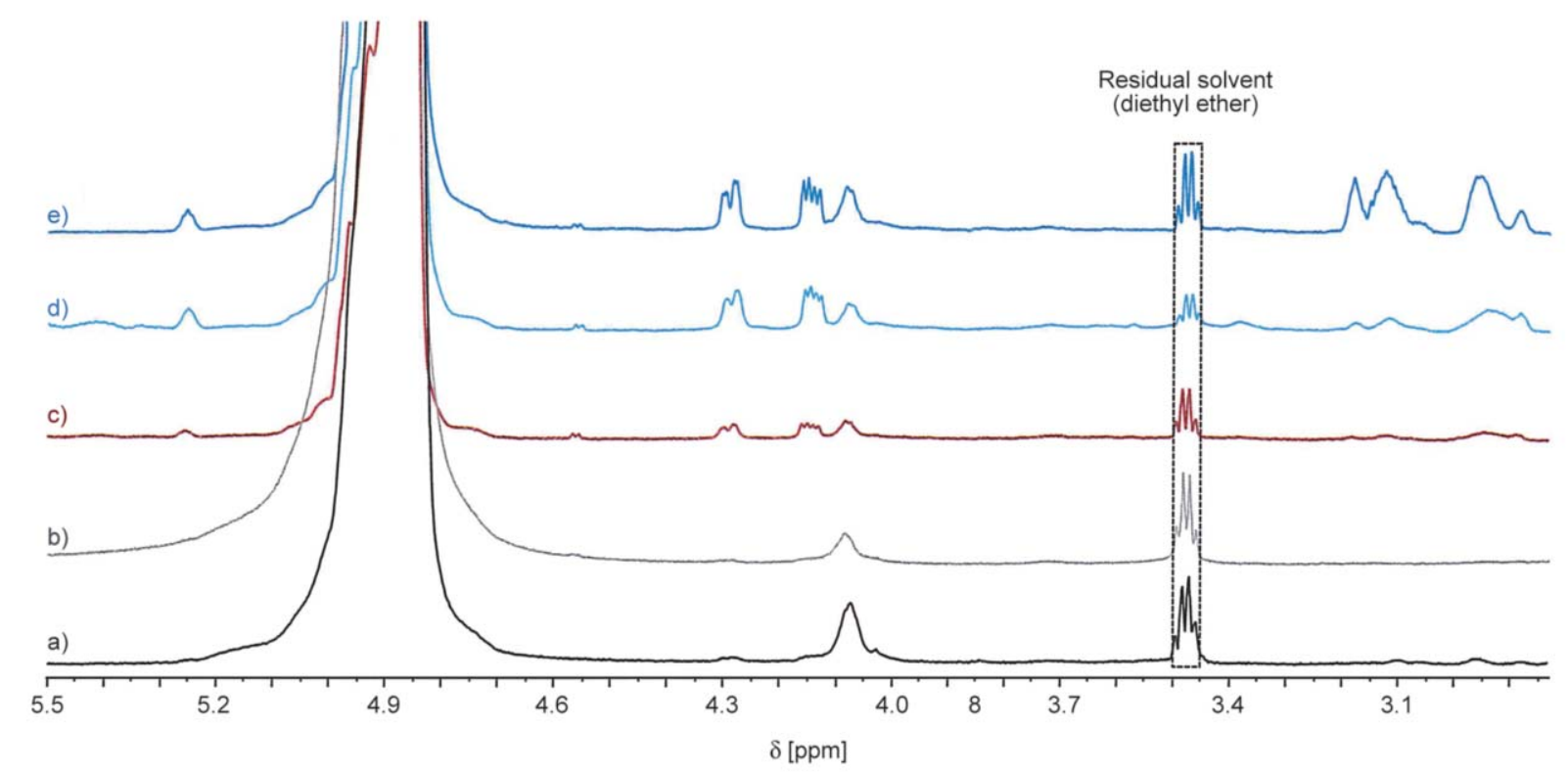

Figure 6. ${ }^{1} \mathrm{H}-\mathrm{NMR}$ spectrum of VAc-ESO ${ }^{\circledR}$ (a), VAc-ELO3 (b), VAc-ELO2 (c), VAc-ELO1 (d), VAc-ELO ${ }^{\circledR}$ (e) copoly$\mathrm{mer} /$ polymer, the ratio of VAc/oil $=1 / 1(\mathrm{w} / \mathrm{w})$ 


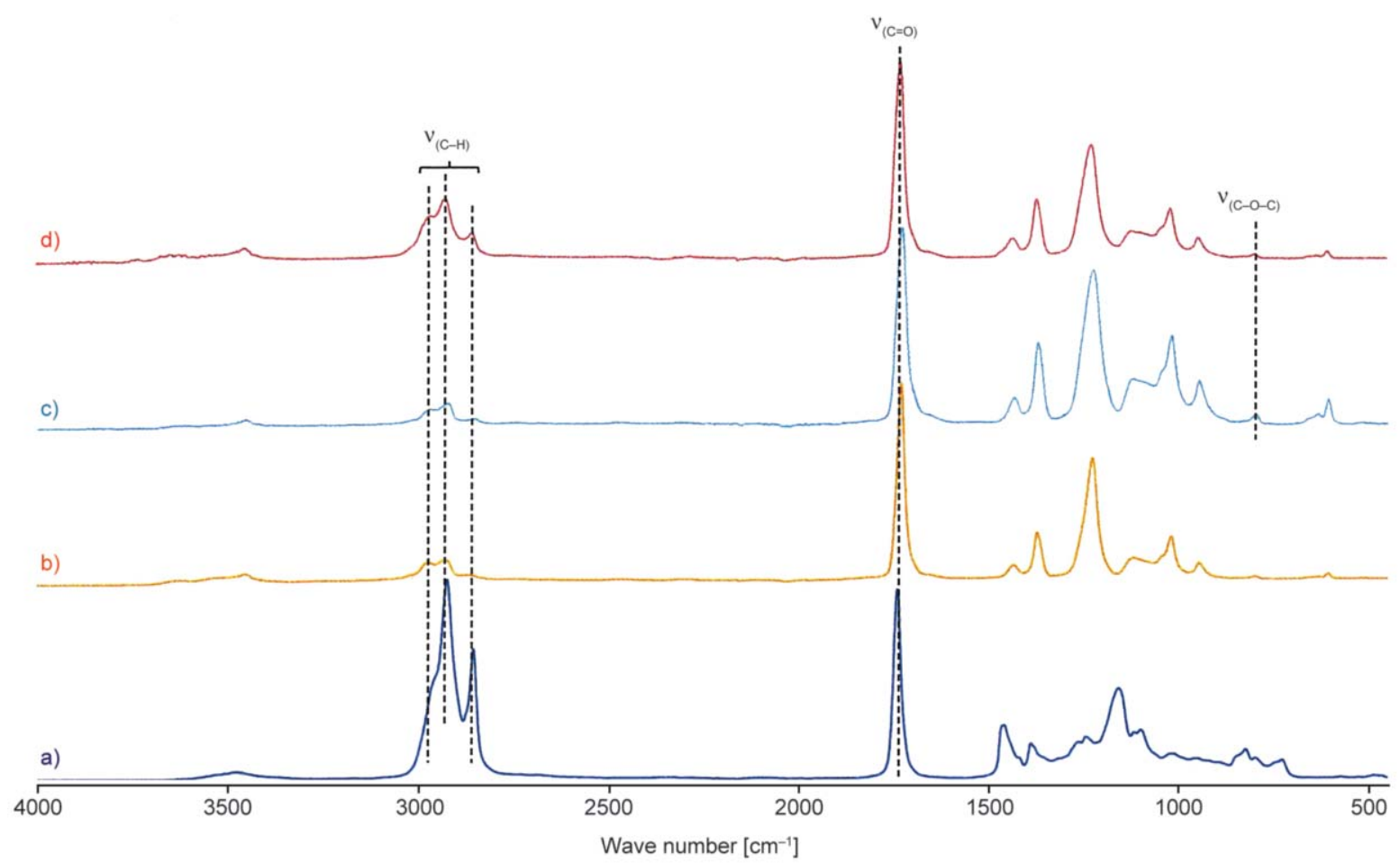

Figure 7. FTIR spectra of $\operatorname{ELO}^{\circledR}(\mathrm{a})$, PVAc (b), VAc-ELO2 copolymer (c), and VAc-ELO ${ }^{\circledR}$ copolymer (d) $($ VAc/oil = 1/1, $(\mathrm{w} / \mathrm{w}))$

constant agitation is required for wood impregnation. Three options were tested in this study, and the effects of formulations and WPG on the decay resistance of VAc-ELO ${ }^{\circledR}$ treated wood are shown in Table 4.

The polymerization of VAc-ELO ${ }^{\circledR}$ initiated by BPO in Formulation 1 was performed in neutral condition, in which no chemical reaction occurs between the resulting copolymer and the reactive part of wood components. The VAc-ELO ${ }^{\circledR}$ treated samples with 23\% WPG show better decay resistance against white rot fungus (Trametes versicolor) than the brown rot fungi (Postia placenta and Coniophora puteana). However, the treatment using Formulation 1 cannot provide sufficient protection against fungi attack. To facilitate the reaction between wood hydroxyl groups and the VAc-ELO ${ }^{\circledR}$ copolymer, aqueous-soluble catalysts were required. Emulsifiers were used to integrate immiscible VAc and $\mathrm{ELO}^{\circledR}$ with water, since neither VAc nor $\mathrm{ELO}^{\circledR}$ were miscible with water.

Table 4. ML after fungal exposure for control and VAc-ELO ${ }^{\circledR}\left(\mathrm{VAc} / \mathrm{ELO}^{\circledR}=1 / 1, \mathrm{w} / \mathrm{w}\right)$ treated samples produced from different formulations (standard deviations in parentheses)

\begin{tabular}{|c|c|c|c|c|c|}
\hline & \multirow[b]{2}{*}{ WPG } & \multicolumn{4}{|c|}{ ML after fungal exposure and calculated durability class (DC) } \\
\hline & & $\begin{array}{c}\text { Trametes versicolor (ML) } \\
{[\%]}\end{array}$ & $\begin{array}{c}\text { Postia placenta (ML) } \\
{[\%]}\end{array}$ & $\begin{array}{c}\text { Coniophora puteana (ML) } \\
{[\%]}\end{array}$ & DC \\
\hline \multicolumn{6}{|c|}{ Formulation $1\left(V A c, E L O^{\mathbb{R}}, B P O\right)$} \\
\hline \multirow[t]{2}{*}{$23 \%$} & Treated & $3.2(0.9)$ & $24.9(10.0)$ & $12.7(7.7)$ & 3 \\
\hline & Control & $18.2(2.8)$ & $45.7(5.4)$ & $39.6(5.8)$ & \\
\hline \multicolumn{6}{|c|}{ Formulation $2\left(\mathrm{VAc}, \mathrm{ELO}^{\circledR}, \mathrm{H}_{2} \mathrm{O}, \mathrm{Brij}^{\circledR} \mathrm{S} 100, \mathrm{Na}_{2} \mathrm{CO}_{3}, \mathrm{~K}_{2} \mathrm{~S}_{2} \mathrm{O}_{8}\right)$} \\
\hline \multirow[t]{2}{*}{$49 \%$} & Treated & $3.7(1.9)$ & $21.2(7.3)$ & $10.2(5.8)$ & 3 \\
\hline & Control & $15.7(5.2)$ & $46.1(6.6)$ & $33.0(2.9)$ & \\
\hline \multicolumn{6}{|c|}{ Formulation $3\left(V A c, E L O^{\circledR}, H_{2} O, C T A B, \operatorname{Span}^{\circledR} 80, K_{2} S_{2} O_{8}\right)$} \\
\hline \multirow[t]{2}{*}{$26 \%$} & Treated & $0.7(0.3)$ & $0.3(0.1)$ & $0.5(0.2)$ & 1 \\
\hline & Control & $23.0(2.1)$ & $58.4(2.4)$ & $53.4(5.8)$ & \\
\hline \multirow[t]{2}{*}{$13 \%$} & Treated & $0.1(1.9)$ & $-2.3(0.4)$ & $-1.0(0.7)$ & 1 \\
\hline & Control & $24.7(3.8)$ & $59.5(1.3)$ & $53.9(4.0)$ & \\
\hline \multirow[t]{2}{*}{$8 \%$} & Treated & $4.4(2.5)$ & $-0.9(0.9)$ & $1.1(0.2)$ & 2 \\
\hline & Control & $25.1(2.9)$ & $59.4(2.3)$ & $55.9(7.7)$ & \\
\hline \multirow[t]{2}{*}{$5 \%$} & Treated & $8.1(2.7)$ & $0.3(0.1)$ & $1.3(0.5)$ & 3 \\
\hline & Control & $23.4(3.3)$ & $58.2(1.5)$ & $51.4(7.0)$ & \\
\hline
\end{tabular}


Brij ${ }^{\circledR} \mathrm{S}\left(3 \mathrm{wt} \%\right.$, average $M_{\mathrm{n}}$ equals $\left.4.670 \mathrm{~g} \cdot \mathrm{mol}^{-1}\right)$ used in Formulation 2 serves as a non-ionic emulsifier to integrate VAc and $\mathrm{ELO}^{\circledR}$ in aqueous phase. $\mathrm{Na}_{2} \mathrm{CO}_{3}(1 \%)$ in Formulation 2 was used to catalyse the reaction between VAc-ELO ${ }^{\circledR}$ copolymer and wood hydroxyl groups by maintaining emulsion in alkaline condition. The durability of treated samples with even higher WPG (49\%) in Formulation 2 is comparable to that of treated samples from Formulation 1, which shows slightly improved resistance to fungal attack. Furthermore, due to the high molecular weight of Brij ${ }^{\circledR}$ S 100 used as emulsifier in the Formulation 2, the obtained emulsions were highly viscous which limits the penetration of the impregnating agents into the wood cell wall. Moreover, the dissolution of Brij ${ }^{\circledR}$ S 100 (granular form) in aqueous solution at room temperature is time-consuming, which is not favourable in industry. The Brij ${ }^{\circledR}$ S 100 was substituted by a combination of emulsifiers CTAB and $\mathrm{Span}^{\circledR} 80$ in Formulation 3. CTAB is well known as an efficient emulsifier used in household products such as shampoos and cosmetics. CTAB (2.6 wt\%) combined with $\mathrm{Span}^{\circledR} 80(1.6 \mathrm{wt} \%)$ can stabilize the VAc-ELO ${ }^{\circledR}$ emulsion for several days. Compared to Brij ${ }^{\circledR} \mathrm{S} 100$ (3 wt\%), the synergistic effect of CTAB and $\operatorname{Span}^{\circledR} 80$ can substantially decrease the viscosity of the solution, which facilitates the impregnation of the emulsion into the wood. Additionally, due to the alkaline character of CTAB, it is presumed that the emulsifier CTAB can catalyse the reaction between $\mathrm{ELO}^{\circledR}$ 's epoxide groups and the wood's hydroxyl groups by ring opening of epoxide groups. By using Formulation 3, the durability of VAcELO $^{\circledR}$ treated samples with $26 \%$ WPG is significantly improved compared to control samples. However, treated wood with $26 \%$ WPG is too heavy and costly, which is not economically viable. Durability tests were carried out further on treated samples with lower WPG (5, 8 and 13\%) to search for an optimal WPG against fungal attack. The protective effectiveness of VAc-ELO ${ }^{\circledR}$ treated wood at different WPG against white rot- (Trametes versicolor) and brown rot fungi (Postia placenta and Coniophora puteana) show that treated samples of $8 \%$ WPG is enough to ensure decay resistance against these test fungi (DC 2), which can be used in above ground applications. In comparison with wood treated only with plant oil (e.g. ELO ${ }^{\circledR}$ and LO) at low retention [16], the durability of wood treated with the VAc-ELO ${ }^{\circledR}$ copolymer produced from Formulation 3 is improved significantly, even at relatively low WPG of $8 \%$.

\section{Conclusions}

The present work investigated the effects of epoxidation degree of $\mathrm{LO}$ and $\mathrm{SO}$ on the copolymerization reaction between epoxidized oil and VAc. Since the epoxidized oil can be chemically produced by insitu epoxidation of the corresponding plant oil, the epoxidized oils with different epoxy content were prepared by controlling the reaction time during the epoxidation process. The number of epoxy groups per oil molecule and the DOE can be determined by means of ${ }^{1} \mathrm{H}-\mathrm{NMR}$. Results showed that the reaction between VAc and epoxidized oil depends on the degree of epoxidation, and also on the types of oil used (i.e. degree of unsaturation). The SO and its derivatives showed no reaction with VAc, while reaction between VAc and epoxidized LO with high epoxy content yielded more product than that of the epoxidized LO having relatively low epoxy content. Plant oil having higher IV before epoxidation and more epoxy content after epoxidation showed higher reactivity towards VAc, and the maximum epoxidized $\mathrm{LO}$ (i.e. $\mathrm{ELO}^{\circledR}$ ) is considered to be the most reactive monomer compared to the other partly epoxidized LO and partly epoxidized SO in copolymerization reaction with VAc. The epoxidized LO with high epoxy content (i.e. $\mathrm{ELO}^{\circledR}$ ) was selected for further investigation on the impact of the VAc-ELO ${ }^{\circledR}$ treatment on the wood durability. As an efficient compound used in household products such as shampoos and cosmetics, a small amount of CTAB (2.6 wt $\%$ ) contained in Formulation 3 serves as a emulsifier for the VAcELO $^{\circledR}-\mathrm{H}_{2} \mathrm{O}$ solution and a catalyst for the reaction between $\mathrm{ELO}^{\circledR}$ 's epoxide groups and wood's hydroxyl groups. Compared to the Formulation 1 and 2, wood treatment by Formulation 3 showed significantly improved durability against white rot- and brown rot fungi. Further study on the durability of treated wood produced from Formulation 3 at four different WPG showed that treated wood of $8 \%$ WPG was sufficient to ensure decay resistance against the test fungi (durability class 2 ).

\section{Acknowledgements}

The authors would like to acknowledge Peter Agback (Department of Chemistry and Biotechnology, SLU-Uppsala) for his technical assistance with the ${ }^{1} \mathrm{H}-\mathrm{NMR}$ and ${ }^{13} \mathrm{C}-\mathrm{NMR}$ experiments. 


\section{References}

[1] Meier M. A., Metzger J. O., Schubert U. S.: Plant oil renewable resources as green alternatives in polymer science. Chemical Society Reviews, 36, 1788-1802 (2007). https://doi.org/10.1039/B703294C

[2] Xia Y., Larock R. C.: Vegetable oil-based polymeric materials: Synthesis, properties, and applications. Green Chemistry, 12, 1893-1909 (2010).

https://doi.org/10.1039/C0GC00264J

[3] Schuchardt U., Sercheli R., Vargas R. M.: Transesterification of vegetable oils: A review. Journal of the Brazilian Chemical Society, 9, 199-210 (1998). https://doi.org/10.1590/S0103-50531998000300002

[4] Li F., Larock R. C.: Thermosetting polymers from cationic copolymerization of tung oil: Synthesis and characterization. Journal of Applied Polymer Science, 78, 1044-1056 (2000).

https://doi.org/10.1002/1097-4628(20001031)78:5<1044::AIDAPP130>3.0.CO;2-A

[5] Li F., Larock R. C.: New soybean oil-styrene-divinylbenzene thermosetting copolymers. I. Synthesis and characterization. Journal of Applied Polymer Science, 80, 658-670 (2001).

https://doi.org/10.1002/1097-4628(20010425)80:4<658::AIDAPP1142>3.0.CO;2-D

[6] Li F., Hanson M., Larock R.: Soybean oil-divinylbenzene thermosetting polymers: Synthesis, structure, properties and their relationships. Polymer, 42, 1567-1579 (2001).

https://doi.org/10.1016/S0032-3861(00)00546-2

[7] Li F., Hasjim J., Larock R. C.: Synthesis, structure, and thermophysical and mechanical properties of new polymers prepared by the cationic copolymerization of corn oil, styrene, and divinylbenzene. Journal of Applied Polymer Science, 90, 1830-1838 (2003).

https://doi.org/10.1002/app.12826

[8] Guo A., Cho Y., Petrović Z. S.: Structure and properties of halogenated and nonhalogenated soy-based polyols. Journal of Polymer Science Part A: Polymer Chemistry, 38, 3900-3910 (2000).

https://doi.org/10.1002/1099-0518(20001101)38:21<3900:: AID-POLA70>3.0.CO;2-E

[9] Saithai P., Lecomte J., Dubreucq E., Tanrattanakul V.: Effects of different epoxidation methods of soybean oil on the characteristics of acrylated epoxidized soybean oil-co-poly(methyl methacrylate) copolymer. Express Polymer Letter, 7, 910-924 (2013).

https://oi.org/10.3144/expresspolymlett.2013.89

[10] Saithai P., Lecomte J., Dubreucq E., Tanrattanakul V.: Bioplastic nanocomposite prepared from acrylated epoxidized soybean oil-PMMA copolymer and nano-titanium dioxide. Advanced Science Letters, 19, 862-865 (2013).

https://doi.org/10.1166/asl.2013.4811

[11] Saurabh T., Patnaik M., Bhagt S., Renge V.: Epoxidation of vegetable oils: A review. International Journal of Advanced Engineering Technology, 2, 491-501 (2011).
[12] Rüsch gen. Klaas M., Warwel S.: Complete and partial epoxidation of plant oils by lipase-catalyzed perhydrolysis. Industrial Crops and Products, 9, 125-132 (1999). https://doi.org/10.1016/S0926-6690(98)00023-5

[13] Caillol S., Desroches M., Boutevin G., Loubat C., Auvergne R., Boutevin B.: Synthesis of new polyester polyols from epoxidized vegetable oils and biobased acids. European Journal of Lipid Science and Technology, 114, 1447-1459 (2012).

https://doi.org/10.1002/ejlt.201200199

[14] Jebrane M., Fernández-Cano V., Panov D., Terziev N., Daniel G.: Novel hydrophobization of wood by epoxidized linseed oil. Part 1. Process description and antiswelling efficiency of the treated wood. Holzforschung, 69, 173-177 (2015).

https://doi.org/10.1515/hf-2014-0029

[15] Dubey M. K., Pang S., Walker J.: Oil uptake by wood during heat-treatment and post-treatment cooling, and effects on wood dimensional stability. European Journal of Wood and Wood Products, 70, 183-190 (2012).

https://doi.org/10.1007/s00107-011-0535-1

[16] Panov D., Terziev N.: Plant oils as 'green' substances for wood protection. in 'EcoWood 2010, Minimizing the Environmental Impact of the Forest Products Industries. Porto, Portugal', 143-149 (2011).

[17] Humar M., Lesar B.: Efficacy of linseed- and tung-oiltreated wood against wood-decay fungi and water uptake. International Biodeterioration and Biodegradation, 85, 223-227 (2013). https://doi.org/10.1016/j.ibiod.2013.07.011

[18] Evans P. D., Wingate-Hill R., Cunningham R. B.: Wax and oil emulsion additives: How effective are they at improving the performance of preservative-treated wood? Forest Products Journal, 59, 66-70 (2009).

[19] Ulvcrona T., Flæte P. O., Alfredsen G.: Effects of lateral wood zone on brown rot resistance of untreated and linseed oil-impregnated Scots pine wood. European Journal of Wood and Wood Products, 70, 771-773 (2012). https://doi.org/10.1007/s00107-012-0604-0

[20] Temiz A., Akbas S., Panov D., Terziev N., Alma M. H., Parlak S., Kose G.: Chemical composition and efficiency of bio-oil obtained from giant cane (Arundo donax L.) as a wood preservative. BioResources, 8, 20842098 (2013). https://doi.org/10.15376/biores.8.2.2084-2098

[21] EN 350-1: Durability of wood and wood-based products-natural durability of solid wood: Guide to the principles of testing and classification of the natural durability of wood (1994).

[22] Jebrane M., Cai S., Panov D., Yang X., Terziev N.: Synthesis and characterization of new vinyl acetate grafting onto epoxidized linseed oil in aqueous media. Journal of Applied Polymer Science, 132, 42089/1-42089/9 (2015).

https://doi.org/10.1002/app.42089

[23] Erbil Y. H.: Vinyl acetate emulsion polymerization and copolymerization with acrylic monomers. CRC press, Boca Raton (2000). 
[24] Zhang Y., Gu J., Tan H., Shi J., Di M., Zuo Y., Qiu S.: Preparation and characterization of film of poly vinyl acetate ethylene copolymer emulsion. Applied Surface Science, 276, 223-228 (2013).

https://doi.org/10.1016/j.apsusc.2013.03.071

[25] Salvini A., Saija L., Finocchiaro S., Gianni G., Giannelli C., Tondi G.: A new methodology in the study of PVAcbased adhesive formulations. Journal of Applied Polymer Science, 114, 3841-3854 (2009).

https://doi.org/10.1002/app.31032

[26] Salvini A., Saija L., Lugli M., Cipriani G., Giannelli C.: Synthesis of modified poly(vinyl acetate) adhesives. Journal of Adhesion Science and Technology, 24, 1629 1651 (2010).

https://doi.org/10.1163/016942410X507731

[27] Cowie J. M. G.: Polymers: Chemistry and physics of modern materials. CRC press, Boca Raton (2007).

[28] Moad G., Solomon D. H.: The chemistry of radical polymerization. Elsevier, Oxford (2005).

[29] Farias M., Martinelli M., Bottega D. P.: Epoxidation of soybean oil using a homogeneous catalytic system based on a molybdenum (VI) complex. Applied Catalysis A: General, 384, 213-219 (2010).

https://doi.org/10.1016/j.apcata.2010.06.038
[30] EN 113: Wood perservatives-test method for determining the protective effectiveness against wood destroying basidiomycetes-determination of toxic values (1997).

[31] EN 84: Wood preservatives-accelerated ageing of treated wood prior to biological testing-leaching procedure (1997).

[32] Adhvaryu A., Erhan S.: Epoxidized soybean oil as a potential source of high-temperature lubricants. Industrial Crops and Products, 15, 247-254 (2002).

https://doi.org/10.1016/S0926-6690(01)00120-0

[33] Oyman Z., Ming W., van der Linde R.: Oxidation of drying oils containing non-conjugated and conjugated double bonds catalyzed by a cobalt catalyst. Progress in Organic Coatings, 54, 198-204 (2005).

https://doi.org/10.1016/j.porgcoat.2005.06.004

[34] Xia W., Budge S. M., Lumsden M. D.: New ${ }^{1}$ H NMRbased technique to determine epoxide concentrations in oxidized oil. Journal of Agricultural and Food Chemistry, 63, 5780-5786 (2015).

https://doi.org/10.1021/acs.jafc.5b01719 